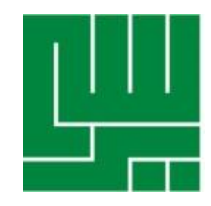

\title{
Self-Compassion dan Resiliensi pada Remaja Panti Asuhan
}

\section{Self-Compassion and Resilience among Adolescents Living at Social Shelters}

\author{
Annisa Zahra Kawitri, Bellatrix Dwi Rahmawati, Ratih Arruum \\ Listiyandini, Rina Rahmatika \\ Fakultas Psikologi, Univesitas YARSI, Jl. Letnan Jendral Suprapto, Cempaka Putih Jakarta \\ 10510, Indonesia \\ Email: rara.annzaka@gmail.com
}

\begin{abstract}
KATA resiliensi, self-compassion, remaja, panti asuhan
KUNCI resilience, self-compassion, adolescents, social shelters

KEYWORDS
\end{abstract}

ABSTRAK Compassion dengan resiliensi pada remaja yang tinggal di panti asuhan.

compassion dengan resiliensi pada remaja yang tinggal di panti asuhan. Sampel penelitian ini adalah 140 remaja panti asuhan dengan karakteristik usia 14-18 tahun yang dipilih dengan teknik convenience sampling dari 12 panti asuhan di Jakarta dan Bekasi. Penelitian ini mengunakan adaptasi alat ukur Self Compassion dan resiliensi. Hasil uji korelasi menemukan bahwa terdapat hubungan positif yang signifikan antara self-compassion dengan resiliensi pada remaja di panti asuhan $(\mathrm{r}=0,439, \mathrm{p}=0.00)$. Hasil penelitian dapat menjadi acuan mengenai pentingnya memberi perhatian terhadap self-compassion dalam mengembangkan resiliensi bagi remaja yang tinggal di panti asuhan

ABSTRACT The aim of this study is to investigate the correlation between selfcompassion and resilience among adolescents who live in social shelters. The sample of this study were 200 adolescents with characteristic of 1418 years of age adolescents selected by convenience sampling technique from 12 youth institutions in Jakarta and Bekasi. This study used adaptation of self-compassion and resilience scale. The statistical test used pearson-product moment correlation. The result was found that there was a significant and positive correlation between self-compassion and resilience among adolescents in social shelters. In this case, higher self-compassion will be followed by higher resilience of adolescent in social shelters. This result could be a reference for the importance of giving attention to self-compassion in order to increase the resilience among adolescents living in social shelter

\section{PENDAHULUAN}

Remaja yang tinggal di panti asuhan merupakan kelompok rentan. Mereka yang tinggal di panti asuhannya biasanya karena mengalami kematian atau perceraian orangtua, kemiskinan, keluarga tidak harmonis, ketidakmampuan orang tua dalam memberikan kasih sayang dan memenuhi kebutuhan hidup anak-anaknya, dan brokenhome dapat menyebabkan hilangnya fungsi keluarga, sehingga anak harus terlepas dari kasih sayang orangtua (Mazaya \& Supradewi, 2011; Rifai, 2015).

Di panti asuhan, sebagian besar remaja belum cukup memperoleh perhatian dari pengasuh karena jumlah pengasuh yang berperan sebagai orangtua tidak sebanding dengan jumlah remaja yang diasuh sehingga para pengasuh diharuskan 
untuk bergantian dalam menjalankan tugasnya di panti asuhan. Kualitas perhatian akan berkurang karena banyaknya anak yang harus diperhatikan (Sandri, 2015). Minimnya kualitas perhatian membuat remaja di panti asuhan rentan mengalami tekanan psikologis yang lebih besar dibandingkan dengan remaja yang tidak tinggal di panti asuhan (Sandri, 2015). Pada studi awal ditemukan bahwa remaja di panti asuhan mengalami perasaan terbuang yang menjadi indikator adanya pengalaman traumatik dan stres. Menurut Yosep, Puspowati, dan Sriati (2009), pengalaman traumatik akan sulit dilupakan dan memiliki efek psikologis dalam waktu yang panjang.

Kondisi ini menyebabkan remaja panti asuhan menjadi kurang mendapatkan kasih sayang, perhatian dan bimbingan secara mendalam serta penurunan pencapaian akademik (Rifai, 2014; Yendork \& Somhlaba, 2014). Mereka juga menjadi kurang dapat berekspresi karena adanya peraturan yang harus ditaati. Hal tersebut akan memunculkan emosi negatif pada remaja di panti asuhan.

Di sisi lain, individu akan lebih mampu menetralisir emosi negatif yang muncul melalui menerima diri dengan apa adanya (Sarwono, 2000). Kondisi penerimaan diri seutuhnya berhubungan dengan suatu konsep psikologi positif, yaitu self-compassion. Individu yang memiliki self-compassion digambarkan sebagai individu yang tidak mudah menyalahkan diri jika gagal, memperbaiki kesalahan, mengubah perilaku yang kurang produktif dan mampu menghadapi tantangan baru (Hidayati, 2014). Mereka akan memiliki disposisi kepribadian berupa ketenangan, empati, kepekaan, kehangatan dan kesabaran dalam menghadapi permasalahannya.

Hasil wawancara dan observasi pada studi awal yang dilakukan oleh peneliti di Panti Asuhan X Bekasi dan Panti Asuhan Y Jakarta diperoleh bahwa mereka merasa cemas akan informasi tentang sekolah dikarenakan tidak adanya alat komunikasi sehingga menghambat kegiatan sekolah di luar jadwal yang sudah ditentukan dan tugas-tugas yang tiba-tiba diberikan oleh gurunya, merasa kesulitan dalam memahami pelajaran yang sulit, serta cemas akan masa depan ketika mereka lulus dari sekolah menengah atas (SMA/SMK) dikarenakan batas waktu yang sudah ditetapkan oleh pihak panti asuhan untuk tinggal dan menerima bantuan ekonomi. Diperoleh pula sebesar $80 \%$ remaja di panti asuhan tidak dapat tenang dalam situasi yang menekan. Dalam kondisi seperti ini, mereka membutuhkan self-compassion agar mampu menerima segala tantangan eksternal yang terjadi dalam hidupnya, terkait masalah dengan keluarga, sekolah, maupun masa depan yang tidak pasti.

Selain self-compassion, resiliensi juga dibutuhkan bagi remaja di panti asuhan. Terdapat beberapa aspek yang membentuk resiliensi. Aspek-aspek tersebut yaitu kompetensi personal, standar yang tinggi dan keuletan, percaya kepada diri sendiri, memiliki toleransi terhadap afek negatif dan kuat dalam menghadapi tekanan, penerimaan positif terhadap perubahan, hubungan yang baik dengan orang lain, pengendalian diri, dan spiritualitas (Connor \& Davidson, 2003).

Secara umum, resiliensi sangat penting bagi remaja karena perubahan sosial, biologis, dan psikologis yang dialami remaja menuntut mereka untuk adaptif dalam menghadapi masalah (Khabbaz, Behjati, \& Naseri, 2011; Athigi, Athigi, \& Atighi, 2015). Individu dapat dikatakan resilien saat mampu untuk menghargai diri sendiri, mencari seseorang untuk berbagi ketika ia membutuhkannya dan mencari kekuatan positif untuk bangkit dari masalah (Shatte, dalam Ifdil \& Taufik, 2012). Pada remaja panti asuhan, risiko dari tekanan-tekanan dan risiko buruk yang membahayakan dapat dihindari karena resiliensi akan membantu melindungi untuk mampu bertahan serta bangkit dari masalah yang dialaminya (Napitupulu, 2009).

Beberapa penelitian yang telah dilakukan mengenai hubungan selfcompassion dengan resiliensi, misalnya 
dilakukan oleh Febrinabilah \& Listiyandini (2016), menemukan hubungan positif antara resiliensi dengan self-compassion yang dilakukan pada dewasa muda mantan pencandu narkoba. Terdapat juga penelitian dari Priatni dan Listiyandini (2017) yang menemukan bahwa pada mahasiswa kedokteran, self-compassion berperan dalam resiliensi para mahasiswa kedokteran. Namun demikian, penelitian mengenai seberapa jauh self-compassion dapat mendukung resiliensi masih dibutuhkan. Hal ini karena remaja panti asuhan merupakan populasi rentan yang tumbuh dalam lingkungan dengan kehadiran faktor protektif eskternal (pengasuhan) yang minim dan faktor resiko yang tinggi (kehilangan figur utama pemberi kasih sayang). Dengan demikian, faktor protektif internal seperti selfcompassion perlu digali lebih lanjut manfaatnya. Terlebih lagi, ditemukan pula pada penelitian Saraswati (2016) yang menyatakan terdapat perbedaan selfcompassion antara remaja yang tinggal dengan orang tua dengan remaja panti asuhan, yang mana remaja tinggal dengan orang tua memiliki self-compassion yang lebih tinggi dibandingkan dengan remaja panti asuhan.

Berdasarkan penjelasan tersebut, maka penelitian ini bertujuan untuk menganalisis hubungan antara selfcompassion dengan resiliensi pada remaja di panti asuhan. Peneliti memiliki hipotesis bahwa terdapat hubungan yang signifikan antara self-compassion dengan resiliensi pada remaja di panti asuhan. Penelitian diharapkan dapat memberikan sumbangan pengetahuan dalam ilmu psikologi positif dan psikologi kesehatan, khususnya untuk kajian mengenai self-compassion dan resiliensi pada remaja di panti asuhan. Selain itu, hasil penelitian ini diharapkan dapat membantu remaja di panti asuhan mengembangkan self-compassion untuk meningkatkan resiliensi dengan pantuan praktisi psikologi klinis.

\section{Self-Compassion}

Self-compassion didefinisikan sebagai pemahaman dan kebaikan kepada diri sendiri ketika menghadapi penderitaan, mengalami sebuah kegagalan maupun membuat kesalahan dengan tidak menghakimi terhadap kekurangan ataupun kelemahan, ketidaksempurnaan, kegagalan individu, dan mengakui bahwa pengalaman diri sendiri adalah bagian dari pengalaman manusia pada umumnya (Neff, 2003). Menurut Neff (2018) self-compassion mulai berkembang pada remaja dalam rentang usia 14-18 tahun. Self-compassion memiliki enam dimensi, yaitu self-kindness, selfjudgement, common humanity, isolation, mindfulness dan over-identification. Faktorfaktor yang mempengaruhi self-compassion antara lain jenis kelamin, tingkat sosial ekonomi, simtom psikopatologis, pengasuhan orangtua, attachment, budaya, dan kepribadian.

\section{Resiliensi}

Connor dan Davidson (2003) mendefinisikan resiliensi sebagai sebuah kualitas personal seseorang yang memungkinkannya untuk berkembang dalam menghadapi kesulitan dalam hidup. Kualitas personalnya yang dimilikinya, diharapkan individu yang mengalami kesulitan dalam hidup dapat bangkit dan tidak kalah dengan keadaan. Terdapat lima aspek resiliensi, yaitu kompetensi personal, standar yang tinggi, dan keuletan; percaya pada diri sendiri, memiliki toleransi terhadap afek negatif dan kuat dalam menghadapi stress; menerima positif terhadap perubahan dan hubungan yang baik dengan orang lain; pengendalian diri; dan pengaruh spiritual. Menurut Ahern (2006) terdapat faktor pendukung (protective factor) dan faktor risiko (risk factor) yang dapat mempengaruhi resiliensi. Faktor pendukung antara lain adalah faktor individual, faktor keluarga, faktor komunitas, dan faktor budaya. Faktor risiko antara lain adalah kejadian katastropik (bencana alam, kematian anggota keluarga, dan perceraian), latar belakang kondisi 
sosial ekonomi keluarga yang kurang mendukung, hidup di lingkungan negatif atau lingkungan yang rawan terjadi tindak kekerasan, serta peningkatan dari beberapa faktor risiko.

\section{METODE}

\section{Pendekatan dan Desain Penelitian}

Penelitian ini menggunakan metode kuantitatif, studi korelasional, dan dengan desain cross-sectional. Hal ini karena dalam penelitian ini, peneliti hanya mengambil data pengukuran variabel pada satu waktu pengukuran dan tidak mengikuti perkembangan longitudinal dari masa ke masa.

\section{Partisipan Penelitian}

Karakteristik subjek yang digunakan dalam penelitian ini yaitu remaja panti asuhan yang tinggal menetap di panti asuhan di Jakarta dan Bekasi, dengan rentang usia 14-18 tahun. Dengan menggunakan teknik convenience sampling, didapatkan 140 subjek yang tersebar di 12 panti asuhan di Jakarta dan Bekasi. Peneliti menggunakan 140 sampel remaja panti asuhan dengan rata-rata usia $\mu=15,76(\mathrm{SD}=$ 1,34), dengan jenis kelamin laki-laki $(52,14 \%)$ dan perempuan $(47,86 \%)$. Domisili panti asuhan di Jakarta $(68,57 \%)$ dan Bekasi (31,43\%). Beberapa penyebab mereka tinggal di panti asuhan adalah karena kondisi ekonomi $(57,14 \%)$, salah satu orangtua meninggal $(30 \%)$, kedua orangtua meninggal $(4,29)$, dan lainnya misalnya tinggal di jalanan $(8,57 \%)$. Remaja di panti asuhan memiliki significant others, yaitu teman $(57,85 \%)$, pengasuh $(34,28 \%)$, orangtua $(5,73 \%)$, dan kerabat $(2,14 \%)$

\section{Instrumen Penelitian}

Peneliti menggunakan adaptasi alat ukur Self Compassion Scale (SCS) yang dirancang oleh Neff (2003) untuk mengukur self-compassion dan sudah diadaptasi oleh Listiyandini dan Febrinabilah (2016). Self Compassion Scale terdiri dari 26 aitem. Skor self-compassion diperoleh dari hasil pengukuran menggunakan skala Likert yang terdiri dari aitem aspek positif dan aitem aspek negatif dengan lima alternatif pilihan jawaban: hampir tidak pernah (1), jarang (2), kadangkadang (3), sering (4), hampir selalu (5). Hasil uji coba SCS $(\mathrm{N}=77)$ diperoleh $\alpha=0,788$ dengan validitas aitem dalam rentang nilai $r=0,119-0,540$. Item yang tidak berfungsi dengan baik tidak dimasukkan ke dalam perhitungan skor total.

Adapun untuk mengukur resiliensi, peneliti menggunakan adaptasi skala resiliensi yang dirancang oleh Connor dan Davidson (2003) dan sudah pernah diadaptasi pada populasi remaja di Indonesia oleh Mujahidah \& Listiyandini (2018) yang mana melalui proses adaptasi alat ukur, yaitu proses backtranslation, expert judgement, uji keterbacaan, serta uji coba. Skala ini terdiri dari 25 aitem dengan model skala Likert lima pilihan jawaban: sangat tidak benar (0), hampir tidak benar (1), kadang-kadang benar (2), seringkali benar (3), hampir setiap saat benar (4) dengan rentang skor total 0-100. Hasil uji coba ulang yang dilakukan pada skala $(\mathrm{N}=157) \quad$ diperoleh $\alpha=0,952$ dengan validitas aitem dalam rentang nilai $r=0,485$ 0,765 .

\section{Teknik Analisis Data}

Metode analisis data yang peneliti gunakan adalah uji korelasi Pearson Product Moment. Pengolahan data dilakukan dengan menggunakan aplikasi JASP 0.8.5 for Windows, SPSS for Windows 20.00 dan Microsoft Excel. Peneliti menggunakan pedoman dari Sugiyono (2012) dalam menentukan interpretasi tinggi atau rendahnya koefisien korelasi yang diperoleh dari masing-masing dimensi. 
mereka. Oleh karena itu, hipotesis penelitian diterima.

Tabel 1

Kategori Koefisien Korelasi

\begin{tabular}{cc}
\hline $\begin{array}{c}\text { Interval } \\
\text { Koefisien }\end{array}$ & Kategori \\
\hline $0,00-0,199$ & Sangat Rendah \\
$0,20-0,339$ & Rendah \\
$0,40-0,599$ & Sedang \\
$0,60-0,799$ & Kuat \\
$0,80-1,000$ & Sangat Kuat \\
\hline
\end{tabular}

\section{ANALISIS DAN HASIL}

\section{Deskripsi Self-Compassion dan Resiliensi}

Berdasarkan hasil analisa statistik skor Self-Compassion subjek dapat dilihat dari alat ukur Self-Compassion Scale (SCS) dengan rentang skor 26-130. Didapatkan rata-rata Self-Compassion subjek sebesar 76,41. Dapat disimpulkan bahwa, apabila nilai rata-rata $(\mu=76,41)$ maka skor yang diperoleh berdasarkan uji statistik deskriptif termasuk dalam kategori sedang.

Adapun pada variabel resiliensi yang terdiri dari 25 aitem dan 4 pilihan jawaban (rentang skor 0-100), dengan ratarata resiliensi subjek sebesar $\mu=66,54$. Hal ini menunjukkan bahwa subjek memiliki kategori resiliensi yang juga sedang.

\section{Hubungan antara Self-cCmpassion dengan Resiliensi}

Berdasarkan hasil penghitungan menggunakan korelasi Pearson Product moment, ditemukan bahwa terdapat hubungan positif yang signifikan antara self-compassion dengan resiliensi pada remaja panti asuhan $(\mathrm{r}=0,439, \mathrm{p}=0,000$, $\mathrm{p}<0,001)$. Dalam hal ini, semakin tinggi self-compassion yang dimiliki remaja di panti asuhan maka semakin tinggi pula resiliensi remaja panti asuhan. Demikian sebaliknya, semakin tinggi resiliensi yang dimiliki remaja panti asuhan maka semakin tinggi pula self-compassion yang dimiliki

\section{DISKUSI}

Hasil penelitian menunjukkan bahwa self-compassion berhubungan positif dengan resiliensi secara signifikan pada remaja yang ditinggal di panti asuhan dengan kekuatan hubungan yang sedang. Hal ini mengindikasikan bahwa semakin tinggi self-compassion, maka semakin tinggi resiliensi yang dimiliki mereka. Hubungan positif antara self-compassion dengan resiliensi juga pernah ditemukan dalam penelitian sebelumnya pada populasi rentan lainnya (Febrinabilah \& Listiyandini, 2015).

Menurut Neff (2013), selfcompassion merupakan suatu perasaan dan pemahaman terhadap kebaikan diri sendiri, keterbatasan diri sebagai manusia, kesadaran utuh dengan tidak menghakimi diri sendiri, tidak mengisolasi diri, dan tidak mengkritik diri secara berlebihan terhadap kekurangan diri. Penelitian yang dilakukan oleh Collins (dalam Neff, 2010) menunjukkan self-compassion juga dapat membantu meningkatkan penghayatan positif mengenai diri sendiri, menghilangkan emosi negatif, serta meningkatkan rasa keterhubungan dengan orang lain. Neff dan McGehee (2010) juga mengemukakan bahwa self-compassion dapat mempengaruhi remaja dalam mengatasi pandangan diri yang negatif.

Pada remaja panti asuhan, jika mereka memiliki self-compassion, maka akan menerima berbagai perasaan dengan tenang sehingga lebih dapat menoleransi emosi negatif. Kemampuan toleransi terhadap emosi negatif juga merupakan bagian dari resiliensi. Hal ini menunjukkan apabila jika remaja panti asuhan memiliki self-compassion yang tinggi, yaitu memiliki kebaikan diri sendiri, tidak mengisolasi dari lingkungan, tidak mengkritik secara berlebihan dan memeliki pemahaman yang positif mengenai diri sendiri, maka individu tersebut mampu kembali segera dalam 
menghadapi dan mengatasi situasi yang berisiko dan penuh tekanan.

Hasil penelitian ini menunjukkan bahwa remaja di panti asuhan yang mampu menyayangi dirinya dengan memahami bahwa sebagai manusia tidaklah sempurna dan seringkali menghadapi berbagai kesulitan serta kegagalan, akan cenderung mampu bangkit dari kesulitan yang dimiliki secara adaptif. Sebaliknya, remaja di panti asuhan yang mengkritik diri secara berlebihan, menolak perasaannya, merasa dirinya adalah satu-satunya yang menderita di dunia, serta memberikan reaksi yang berlebihan ketika menghadapi masalah atau pun kegagalan, maka ia cenderung tidak resilien sehingga dapat memungkinkan timbulnya kecemasan dan depresi.

Penelitian sebelumnya memang juga sudah menemukan bahwa terdapat hubungan yang signifikan antara selfcompassion dengan resiliensi pada remaja dengan kondisi rentan, yaitu pada mereka yang mengalami perceraian orangtua (Hermansyah, 2019). Namun berbeda dengan penelitian tersebut yang hanya melibatkan 36 responden, penelitian ini mengikutsertakan partisipan dengan jumlah yang lebih representatif, yaitu 140 orang, dan partisipan dengan kondisi kehilangan figur orangtua yang lebih spesifik (tinggal di panti asuhan). Dalam penelitian ini, kekuatan hubungan antara resiliensi dan self-compassion berada pada kategori sedang. Kekuatan hubungan pada kategori sedang ini konsisten dengan hasil penelitian sebelumnya yang dilakukan pada populasi lainnya, seperti mahasiswa kedokteran (Priatni \& Listiyandini, 2017) atapun mantan pecandu narkoba (Febrinabilah \& Listiyandini, 2015). Hal ini mengindikasikan bahwa self-compassion merupakan variabel yang ditemukan cukup konsisten berhubungan secara positif dengan resiliensi pada berbagai rentang usia, termasuk pada remaja.

Dalam proses penelitian ini, peneliti menyadari bahwa masih terdapatnya kelemahan dan keterbatasan pada proses penelitian yang dilakukan. Terkait dengan instrumen penelitian, terdapat kemungkinan bahwa alat ukur self-compassion yang cenderung masih sulit dipahami oleh remaja sehingga perlu dilakukan penyederhanaan kata atau penyesuaian pemilihan kata agar dapat lebih dipahami oleh remaja. Selain itu, penelitian selanjutnya juga dapat menelaah mengenai kemungkinan adanya perbedaan self-compassion pada setiap tahapan perkembangan remaja, sehingga dapat diidentifikasi mengenai masingmasing perannya pada setiap tahapan.

\section{SIMPULAN}

Berdasarkan analisis data yang dilakukan peneliti maka dapat disimpulkan bahwa terdapat hubungan positif yang signifikan antara self-compassion dengan resiliensi pada remaja di panti asuhan. Semakin tinggi self-compassion akan diikuti pula oleh tingginya resiliensi.

\section{SARAN}

\section{Saran Metodologis}

1. Terkait dengan instrumen penelitian, pada penelitian selanjutnya untuk populasi remaja dilakukan uji keterbacaan secara lebih mendalam, menyederhanakan terhadap aitem-aitem pada alat ukur self-compassion sehingga dapat lebih dipahami lebih baik oleh remaja.

2. Meneliti perkembangan selfcompassion pada remaja panti asuhan dengan desain longitudinal atau membandingkan perbedaan antar tahapan perkembangan.

\section{Saran Praktis}

Bagi remaja panti asuhan, disarankan untuk mengembangkan rasa kasih bagi diri sendiri untuk mengatasi permasalahan pada setiap aspek kehidupan sehingga membantu terciptanya resiliensi yang baik. Mengingat pentingnya resiliensi, pengelola panti asuhan dapat membuat pelatihan terkait self-compassion, dengan bantuan para praktisi psikologi klinis. Selfcompassion dapat dikembangkan melalui 
restrukturisasi kognitif, body scanning, serta latihan meditasi compassion dan loving kindness.

\section{DAFTAR PUSTAKA}

Ahern, N., Kiehl, E., Sole, M., \& Byers, J. (2006). A review of instrument measuring resilience. Issues in Comprehensive Pediatric Nursing, 29, 103-125.

Atighi, E., Atighi, A., \& Atighi, I. (2015). Predicting psychological resilience based on parenting styles in girl adolescence. International Research Journal of Applied and Basic Sciences, 9(8), 1340-1344.

Connor, K. M., \& Davidson, J. R. (2003). Development of a new resilience scale: the Connor-Davidson Resilience Scale (CD-RISC). Depression and anxiety, 18(2), 76-82.

Febrinabilah, R., \& Listiyandini, R. A. (2016). Hubungan antara self-compassion dengan resiliensi pada mantan pecandu narkoba dewasa awal. In S.E. Hafiz \& F. Rozi (Eds.), Peran Psikologi dalam Pembangunan. Prosiding Konferensi Nasional Peneliti Muda Psikologi Indonesia (pp.19-28). Jakarta, Indonesia.

Hidayati, F. N. R. (2014). Hubungan antara self compassion dengan work family conflict pada staf markas palang merah indonesia provinsi jawa tengah. Jurnal Psikologi Undip, 14(2), 183189.

Hermansyah, M. T. (2019). Hubungan antara self compassion dan resiliensi pada remaja dengan orang tua bercerai (Skripsi). Fakultas Psikologi Universitas Islam Indonesia, Yogyakarta.

Ifdil, I., \& Taufik, T. (2012). Urgensi peningkatan dan pengembangan resiliensi siswa di Sumatera Barat. Pedagogi, 12(2), 115-121.

Khabbaz M, Behjati Z, Naseri M. (2011). The relation between social support, coping styles and resiliency in boy adolescents. Applied Psychology Quarterly, 108-124.

Mazaya, K. N., \& Supradewi, R. (2012). Konsep diri dan kebermaknaan hidup pada remaja di panti asuhan. Jurnal Psikologi Proyeksi, 6(2), 103-112.

Mujahidah, E., \& Listiyandini, R. A. (2018). Pengaruh resiliensi dan empati terhadap gejala depresi pada remaja. Jurnal Psikologi, 14(1), 60-75.

Napitupulu, C. A. (2009). Resiliensi remaja yatim piatu di panti asuhan Mardi Siwi Kalasan Yogyakarta (Skripsi). Universitas Sanata Dharma Yogyakarta, Yogyakarta.

Neff, K. D. (2003). The development and validation of a scale to measure selfcompassion. Self and Identity, 2(3), 223-250.

Neff, K. D. (2016). Does self-compassion entail reduced self-judgment, isolation, and over-identification? A response to Muris, Otgaar, and Petrocchi (2016). Mindfulness, 7(3), 791-797.

Neff, K. D., \& McGehee, P. (2010). Selfcompassion and psychological resilience among adolescents and young adults. Self and Identity, 9(3), 225-240.

Neff, K. D., Whittaker, T. A., \& Karl, A. (2017). Examining the factor structure of the Self-Compassion Scale in four distinct populations: Is the use of a total scale score justified?. Journal of Personality Assessment, 99(6), 596607.

Priatni, M.R., \& Listiyandini, R.A. (2017). The Influence of self-compassion toward psychological resilience among medical students. Proceeding The First South East Asia of Regional Conference on Psychology (RCP). Hanoi, Vietnam.

Rifai, N. (2015). Penyesuaian diri pada remaja yang tinggal di panti asuhan (studi kasus pada remaja yang tinggal di panti asuhan yatim piatu Muhammadiyah Klaten (Disertasi). Universitas Muhammadiyah Surakarta, Surakarta.

Sandri, R. (2015). Perilaku bullying pada remaja panti asuhan ditinjau dari kelekatan dengan teman sebaya dan harga diri. Jurnal Psikologi Tabularasa, 10(1), 43-57.

Saraswati, M.N.P. (2016). Studi diferensial mengenai self-compassion pada remaja yang tinggal di panti asuhan dan remaja yang tinggal dengan orang tua (Skripsi). Fakultas 
Psikologi Universitas Kristen Maranatha, Bandung.

Sarwono, S.W. (2000). Psikologi Remaja. Jakarta: Rajawali.

Sun, X., Chan, D. W., \& Chan, L. K. (2016). Self-compassion and psychological well-being among adolescents in Hong Kong: Exploring gender differences. Personality and Individual Differences, 101, 288-292.

Yendork, S. J., \& Somhlaba, N. Z. (2015). Do social support, self-efficacy and resilience influence the experience of stress in Ghanaian orphans? An exploratory study. Child Care in Practice, 21(2), 140-159. https://doi.org/10.1080/13575279.2014.9 85286

Yosep, I., Puspowati, N. L. N. S., \& Sriati, A. (2009). Pengalaman traumatik penyebab gangguan jiwa (skizofrenia) pasien di Rumah Sakit Jiwa Cimahi. Majalah Kedokteran Bandung, 41 (4). 194-200. 